\title{
Patients with systemic lupus erythematosus and Jaccoud's arthropathy: a clinical subset with an increased $\mathrm{C}$ reactive protein response?
}

\author{
P E Spronk, E J ter Borg, C G M Kallenberg
}

\begin{abstract}
Jaccoud's arthropathy is a chronic deforming synovitis occurring in a subset of patients with systemic lupus erythematosus (SLE). To evaluate whether patients with SLE and Jaccoud's arthropathy behave differently in their acute phase reaction from patients with SLE without Jaccoud's arthropathy, a prospective study was carried out on 72 consecutive patients with SLE. Patients were assessed for Jaccoud's arthropathy according to a protocol, disease activity was scored, and laboratory tests, including tests for $\mathrm{C}$ reactive protein, were performed. Seven patients were classified as having definite Jaccoud's arthropathy. In those patients the serum concentrations of $\mathbf{C}$ reactive protein were higher than in those without Jaccoud's arthropathy, whereas disease activity scores and treatment were comparable. Additionally, patients with Jaccoud's arthropathy had a longer disease duration and a longer history of arthritis than those without, whereas IgM rheumatoid factor was observed more often. The increased concentration of $\mathbf{C}$ reactive protein in patients with Jaccoud's arthropathy is compatible with a persistent inflammatory reaction. Serial testing of $\mathbf{C}$ reactive protein in combination with other laboratory parameters may be a guideline for treatment in patients with SLE and Jaccoud's arthropathy.
\end{abstract}

Joints are affected in $90 \%$ of patients with systemic lupus erythematosus (SLE). ${ }^{1}$ Some patients develop chronic synovitis, predominantly of the metacarpophalangeal and proximal interphalangeal joints, which can result in deformities. Radiologically, this synovitis can be differentiated from the synovitis in rheumatoid arthritis (RA) by the absence of typical erosions, ${ }^{1}$ though the formation of 'hooks' may occur. $^{2}$ These deformities of the hands, also known as Jaccoud's arthropathy, ${ }^{3}$ are seen in $10-35 \%$ of patients with SLE. ${ }^{1}$ Ulnar drift with subluxation of the metacarpophalangeal joints is often the first sign, whereas swan neck, boutonnière deformities, and $\mathrm{Z} Z$ deformity may occur at a later stage. ${ }^{2}$ Deformities of the hands were first reported by Jaccoud and reinvestigated by Bywaters $^{2}$ in patients with a history of rheumatic fever. Although Jaccoud's arthropathy has been described in a variety of disorders, it is most often observed in patients with SLE. ${ }^{2}$

Little is known about the pathogenesis of Jaccoud's arthropathy. Chronic synovitis together with joint laxity are generally accepted as important factors. ${ }^{2}$ Patients with SLE, in general, have normal or only slightly increased concentrations of $C$ reactive protein in serum, despite disease activity. ${ }^{45}$ We observed moderately increased concentrations of $\mathrm{C}$ reactive protein in serum samples from patients with SLE and Jaccoud's arthropathy, even during periods without clinical disease activity. To evaluate whether patients with SLE and Jaccoud's arthropathy show a chronic persistent inflammatory reaction manifested by an acute phase response different from that of patients with SLE without Jaccoud's arthropathy, we undertook a prospective study on consecutive outclinic patients with SLE to address the following questions: (a) are patients with SLE and Jaccoud's arthropathy characterised by an increased $\mathrm{C}$ reactive protein response during periods without apparent disease activity and (b) do patients with SLE and Jaccoud's arthropathy differ from patients with SLE without Jaccoud's arthropathy with respect to other clinical and serological characteristics?

Patients and methods

Seventy eight consecutive outpatients fulfilling the revised American Rheumatism Association (ARA) criteria for the diagnosis of $\mathrm{SLE}^{6}$ were evaluated during this study. Seventy two patients ( 58 women and 14 men) were included. Excluded from the study were: $(a)$ patients with (signs of) infection occurring within one month before the time of examination; (b) patients with a disease activity score exceeding one point at the time of examination; ${ }^{7}(c)$ patients simultaneously fulfilling the ARA criteria for RA; ${ }^{8}$ and $(d)$ patients showing erosions or joint space narrowing on radiographs of the hands or feet. The median age at the time of the study was 40 years (range 16-74 years). The diagnosis of SLE was established a median of eight years (range 0-28 years) before the time of the study. Forty one patients were receiving prednisolone whereas six patients were receiving non-steroidal anti-inflammatory drugs (NSAIDs) at the time of the study.

\section{PROTOCOL}

Patients were evaluated according to a protocol. In particular, physical examination included a detailed study of the hands according to a standard data form. Previous history, with special attention to cumulative ARA criteria for SLE and RA, was taken from the chart. A validated and previously published disease activity index was calculated from signs and symptoms recorded according to a protocol and 
routine laboratory tests (table 1 ). ${ }^{7}$ Radiographs were taken of the hands and feet at the time of the study. Blood samples were drawn at the time of the study and analysed for serum

Table 1 Disease activity index

\begin{tabular}{|c|c|}
\hline Disease characteristics & $\begin{array}{l}\text { Points } \\
\text { scored }^{*}\end{array}$ \\
\hline $\begin{array}{l}\text { Kidneys } \\
\text { Proteinuria } \\
\text { Newly developed }(>0.5 \mathrm{~g} / \text { day) or } \\
\text { doubling within four months (basal } \\
\text { proteinuria }>0.5 \mathrm{~g} / \text { day) }\end{array}$ & 2 \\
\hline $\begin{array}{l}\text { Erythrocyturia } \\
\text { Newly developed (>5 erys, high power } \\
\text { field) or doubling }\end{array}$ & 1 \\
\hline $\begin{array}{l}\text { Erythrocyte or granular casts, or both } \\
\text { Presence } \\
\text { Newly developed }\end{array}$ & $\frac{1}{2}$ \\
\hline $\begin{array}{l}\text { Creatinine clearance } \\
\text { Decrease of }>25 \% \text { (within four months) }\end{array}$ & 2 \\
\hline $\begin{array}{l}\text { Central nervous systemt } \\
\text { Cerebral vascular accident } \\
\text { Seizure } \\
\text { Psychosis } \\
\text { Choreathetosis } \\
\text { Transverse myelitis } \\
\text { Motoric nerve palsy }\end{array}$ & $\begin{array}{l}4 \\
4 \\
4 \\
4 \\
4 \\
4 \\
4\end{array}$ \\
\hline $\begin{array}{l}\text { Skin/mucosa } \\
\text { Alopeciał } \\
\text { Active discoid rash } \\
\text { Malar rash } \\
\text { Other active rash } \\
\text { Active mouth and/or nasal ulcerations }\end{array}$ & $\begin{array}{l}1 \\
1 \\
2 \\
1 \\
2\end{array}$ \\
\hline $\begin{array}{l}\text { Blood } \\
\text { Haemolytic anaemia }\end{array}$ & \\
\hline $\begin{array}{l}\text { Haemoglobin, }<100 \mathrm{~g} / 1 \\
\text { Haemoglobin, }<80 \mathrm{~g} / 1 \\
\text { Leucopenia }\end{array}$ & $\frac{1}{2}$ \\
\hline $\begin{array}{l}<4.0 \times 10^{9} / 1 \\
<3.0 \times 10^{9} / 1\end{array}$ & $\frac{1}{2}$ \\
\hline $\begin{array}{l}\text { Thrombocytopenia } \\
<100 \times 10^{9} / 1 \\
<50 \times 10^{9} / 1 \\
<25 \times 10^{9} / 1\end{array}$ & $\begin{array}{l}1 \\
2 \\
3\end{array}$ \\
\hline $\begin{array}{l}\text { Musculoskeletal system } \\
\text { Arthralgia or myalgiat, or both } \\
\text { Arthritis ( } \geqslant \text { two joints) and/or tendinitis }\end{array}$ & $\begin{array}{l}1 \\
1\end{array}$ \\
\hline $\begin{array}{l}\text { Serosa } \\
\text { Pleural or pericardial pain, or both } \dagger \\
\text { Pleural or pericardial rub, or both } \\
\text { Abnormalities on chest radiograph, } \\
\text { electrocardiogram or echocardiogram, or both }\end{array}$ & $\begin{array}{l}1 \\
2 \\
2\end{array}$ \\
\hline $\begin{array}{l}\text { Vessels } \\
\text { Minor vasculitis (purpura, periungual infarction) } \\
\text { Major vasculitis (ulcerations, mononeuritis) }\end{array}$ & $\begin{array}{l}2 \\
4\end{array}$ \\
\hline $\begin{array}{l}\text { Miscellaneous } \\
\text { Uveitis or chorioretinitis, or both } \\
\text { Myositis } \\
\text { Rising creatine kinase }>150 \mathrm{U} / 1 \\
\text { Rising creatine kinase }>500 \mathrm{U} / 1\end{array}$ & $\begin{array}{l}2 \\
3\end{array}$ \\
\hline
\end{tabular}

*When an item is related, in all likelihood, to drugs or an unrelated condition, no points are given.

tOnly scored when occurring within two weeks of the time of the outpatient visit or admission under consideration.

Table 2 Index for establishing the diagnosis of Faccoud's arthropathy and characteristics of seven patients who were assigned as having faccoud's arthropathy

\begin{tabular}{|c|c|c|c|}
\hline & \multicolumn{2}{|l|}{ Jaccoud's index } & \multirow{2}{*}{$\begin{array}{l}\text { Occurrence of symptoms } \\
\text { in seven patients with } \\
\text { faccoud's arthropathy: } \\
\text { number of patients } \\
\text { with symptoms (\%) }\end{array}$} \\
\hline & $\begin{array}{l}\text { Number of } \\
\text { affected fingers }\end{array}$ & $\begin{array}{l}\text { Points } \\
\text { assigned }\end{array}$ & \\
\hline Ulnar drift $\left(>20^{\circ}\right)$ & $1-4$ & 2 & $7(100)$ \\
\hline Swan neck deformities & $\begin{array}{l}1-4 \\
5-8\end{array}$ & 2 & $6(86)$ \\
\hline $\begin{array}{l}\text { Limited metacarpophalangeal } \\
\text { joint extension }\end{array}$ & $1-4$ & 1 & $4(57)$ \\
\hline Boutonnière deformities & $1-4$ & 2 & $3(43)$ \\
\hline$Z$ deformity & $2_{2}^{2-0}$ & $\begin{array}{l}3 \\
2 \\
3\end{array}$ & $2(29)$ \\
\hline
\end{tabular}

Jaccoud's arthropathy was considered present if the score of the index exceeded five points. concentrations of $\mathrm{C}$ reactive protein, levels of antibodies to double stranded DNA, antinuclear antibodies, and antibodies to extractable nuclear antigens, IgM rheumatoid factor, and perinuclear factor. Based on the data obtained, the presence of Jaccoud's arthropathy was defined according to criteria given in table 2 .

\section{METHODS}

C reactive protein (normal concentration $<3$ $\mathrm{mg} / \mathrm{l}$ ) was determined by an enzyme linked immunosorbent assay (ELISA). In brief, microtitre plates (Inotech) were coated overnight at room temperature with rabbit antibodies to $C$ reactive protein (Dakopatts, Copenhagen, Denmark), diluted $1: 750$ in $0.1 \mathrm{~mol} / 1$ sodium carbonate, $\mathrm{pH} 9 \cdot 6$. After washing, the wells were incubated with serum samples from patients in dilutions of 1:200 to $1: 12800$ for 45 minutes at $37^{\circ} \mathrm{C}$. Rabbit antibodies to $\mathrm{C}$ reactive protein conjugated to horseradish peroxidase (Dakopatts) were applied at a 1:500 dilution for 30 minutes at $37^{\circ} \mathrm{C}$. The colour reaction was determined by absorbance measurements. After two hours the reaction was stopped and the absorbance was determined at $492 \mathrm{~nm}$ in a Titertek Multiskan. A reference serum sample for $\mathrm{C}$ reactive protein (Behringwerke, Germany) was used as the standard. IgM rheumatoid factor was determined by ELISA as described previously. ${ }^{9}$ Antibodies to double stranded DNA and antinuclear antibodies were detected by indirect immunofluorescence using Crithidia luciliae $^{10}$ and human fetal fibroblasts, ${ }^{11}$ respectively, as a substrate. Perinuclear factor

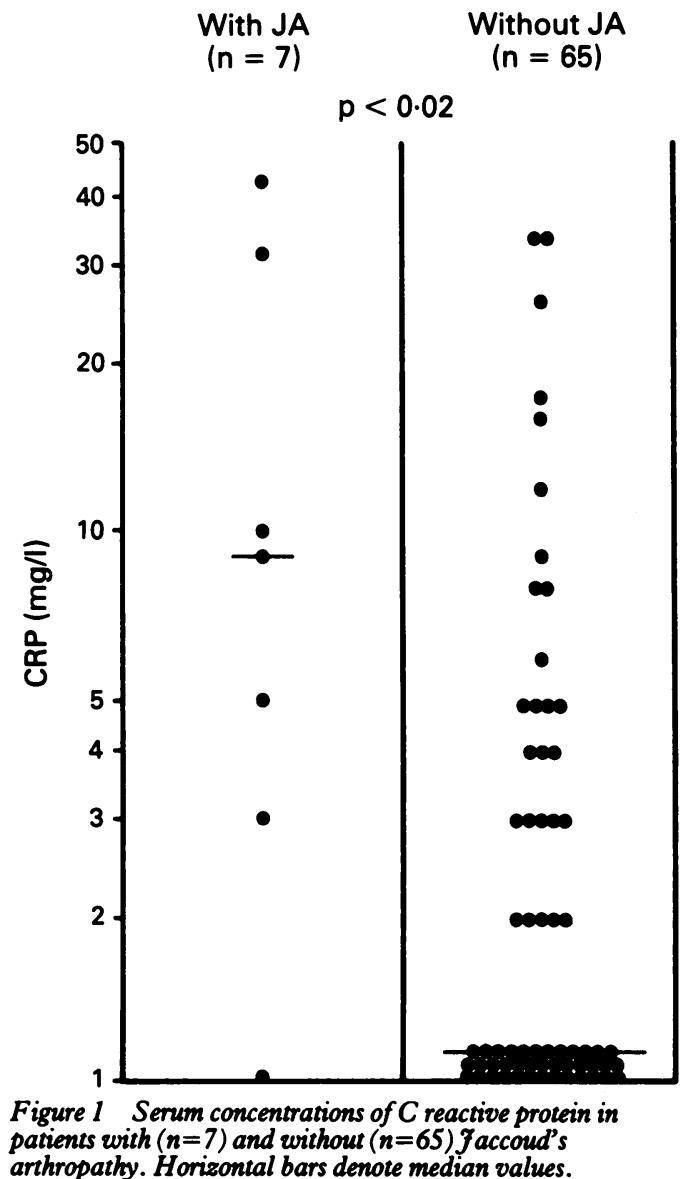


Table 3 Occurrence of clinical symptoms and results of serological tests in 72 patients with SLE with $(\mathfrak{F} A+)$ and without $(\mathfrak{F} A-) \mathcal{F}$ accoud's arthropathy

\begin{tabular}{|c|c|c|}
\hline & $\begin{array}{l}\mathcal{F A +}(\%) \\
(n=7)\end{array}$ & $\begin{array}{l}\mathcal{J A}-(\%) \\
(n=65)\end{array}$ \\
\hline $\begin{array}{l}\text { Cumulative ARA criteria }{ }^{10} \\
\text { Malar rash } \\
\text { Discoid rash } \\
\text { Photosensitivity } \\
\text { Mouth ulceration } \\
\text { Arthritis } \\
\text { Serositis } \\
\text { Renal disorder } \\
\text { Neurological disorder } \\
\text { Haematological disorder } \\
\text { Anti-Sm antibodies } \\
\text { Antibodies to double stranded DNA } \\
\text { Antinuclear antibodies }\end{array}$ & $\begin{array}{ll}3 & (43) \\
1 & (14) \\
4 & (57) \\
1 & (14) \\
6(86) \\
6(86) \\
2(29) \\
2(29) \\
6(86) \\
1(14) \\
4(57) \\
7(100)\end{array}$ & $\begin{array}{c}21(32) \\
10(15) \\
35(54) \\
15(14) \\
49(75) \\
27(42) \\
39(60) \\
26(40) \\
52(80) \\
8(12) \\
37(57) \\
65(100)\end{array}$ \\
\hline $\begin{array}{l}\text { Other clinical characteristics at the time of } t \\
\text { Sicca disorders } \\
\text { Raynaud's phenomenon } \\
\text { Swollen fingers } \\
\text { Sclerodactyly }\end{array}$ & $\begin{array}{l}\text { he study } \\
1(14) \\
4(57) \\
1(14) \\
1(14)\end{array}$ & $\begin{array}{c}11(17) \\
35(54) \\
14(20) \\
4(6)\end{array}$ \\
\hline $\begin{array}{l}\text { Serological characteristics at the time of the } \\
\text { Anti-Sm antibodies } \\
\text { Antibodies to double stranded DNA } \\
\text { Antinuclear antibodies } \\
\text { Anti-nRNP antibodies } \\
\text { Anti-SSA antibodies } \\
\text { Anti-SSB antibodies } \\
\text { IgM rheumatoid factor } \\
\text { Perinuclear factor }\end{array}$ & $\begin{array}{l}\text { study } \\
1 \text { (14) } \\
2(29) \\
7(100) \\
2(29) \\
2(29) \\
1(14) \\
4(57) \\
0(0)\end{array}$ & $\begin{aligned} 8 & (12) \\
21 & (32) \\
65 & (100) \\
10 & (15) \\
25 & (39) \\
2 & (3) \\
8 & (12) \\
1 & (1)\end{aligned}$ \\
\hline
\end{tabular}

was determined according to Nienhuis and Mandema. ${ }^{12}$ Antibodies to extractable nuclear antigens were detected by counterimmunoelectrophoresis according to Kurata and $\operatorname{Tan}^{13}$ using a crude extract of rabbit thymus acetone powder (Pel Freeze, Rogers, AK, USA) as a substrate and reference serum sample, showing identity with the corresponding Centre for Disease Control (Atlanta) references. Three reference serum samples were used: anti-Sm, anti-nRNP, and anti-SSB. Anti-SSA antibodies were detected by counterimmunoelectrophoresis using human spleen extract as a substrate.

\section{STATISTICS}

Differences in parameters between groups were evaluated with the Mann-Whitney rank sum test. For a comparison of differences in occurrence between groups, $\chi^{2}$ analysis was applied. A p value of $\leqslant 0.05$ was considered significant.
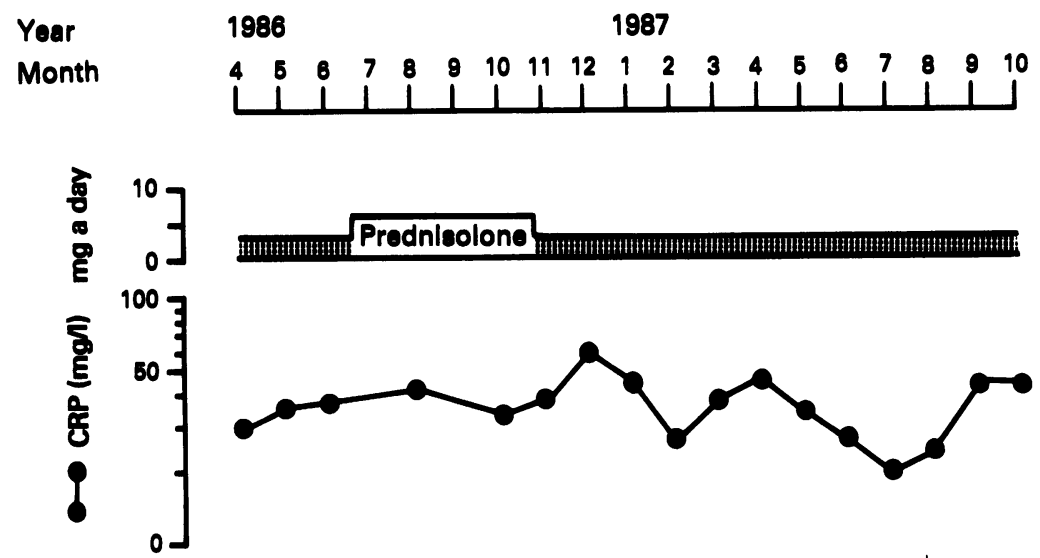

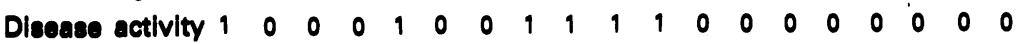
Index (pointe)

Figure 2 Serial concentrations of $C$ reactioe protein, disease activity index, and treatmont in a pationt with SLE and $\mathcal{Y}$ accoud's arthropathy.
Results

Of the 72 patients with SLE, seven fulfilled the criteria for Jaccoud's arthropathy. Ulnar drift $(100 \%)$, swan neck deformities $(86 \%)$, and limited metacarpophalangeal extension ( $57 \%$ ) were the abnormalities most often seen in these patients (table 2). In patients with Jaccoud's arthropathy $(\mathrm{JA}+)$, SLE disease activity scores (median 0 , range $0-2$ ) were comparable with those in patients without Jaccoud's arthropathy (JA-) (median 0, range $0-2 ; \mathrm{NS}$ ). Also, the daily prednisolone doses were comparable in the two groups (JA+, median $8 \mathrm{mg}$, range 0-25; JA-, median $3 \mathrm{mg}$, range 0-35; NS). 'Hooks' on radiographs of the hands, according to Bywaters, 2 were seen in only one patient with Jaccoud's arthropathy.

\section{REACTIVE PROTEIN}

We compared the acute phase reaction between $\mathrm{JA}+$ and JA - patients. Serum concentrations of $\mathrm{C}$ reactive protein were higher in $\mathrm{JA}+$ (median $9 \mathrm{mg} / \mathrm{l}$, range $<3-43$ ) than in JA(median $<3 \mathrm{mg} /$, range $<3-34 ; \mathrm{p}<0.02$ ) patients (fig 1 ). The difference in $\mathrm{C}$ reactive protein concentration between $\mathrm{JA}+$ and $\mathrm{JA}-$ patients was still significant when only patients with a history of arthritis were evaluated.

\section{CLINICAL AND SEROLOGICAL CHARACTERISTICS}

To evaluate whether JA+ patients constitute, apart from the presence of deformities, a distinct subgroup within the range of SLE, we compared the occurrence of cumulative ARA criteria for SLE, other clinical characteristics, and serological findings between $\mathrm{JA}+$ and $\mathrm{JA}-$ patients. Cumulative patient characteristics for $\mathrm{JA}+(\mathrm{n}=7)$ and JA- $(n=65)$ patients at the time of the study are given in table 3 . In patients with Jaccoud's arthropathy, the disease duration was longer than in those without Jaccoud's arthropathy (median $14 v 7$ years; $\mathrm{p}<0.005$ ), and more time had elapsed between the first signs of arthritis and the time of the study (23 v 9 years; $p<0.005)$. The occurrence of a positive level of IgM rheumatoid factor was higher in JA + compared with JA - patients (57 v 12\%; $\mathrm{p}<0.02$ ). No significant differences were found with respect to other clinical and serological characteristics.

\section{LONGITUDINAL OBSERVATIONS}

As an example of a persistently increased concentration of $\mathrm{C}$ reactive protein in the absence of disease activity, fig $\mathbf{2}$ shows serial data on $\mathrm{C}$ reactive protein concentrations, disease activity scores, and treatment from a patient with SLE and Jaccoud's arthropathy.

\section{Discussion}

Although Jaccoud's arthropathy is characterised by a number of deformities, no definite criteria for its diagnosis have been published. To achieve a standard approach to Jaccoud's arthropathy in our study, we developed a Jaccoud's arthropathy index comprising the 
different clinical symptoms and the extent of the deformities (table 2). Using this index, strict criteria were formulated for assessing a diagnosis of definite Jaccoud's arthropathy. Based on these criteria, $10 \%$ of our patients with SLE were assigned as having Jaccoud's arthropathy, which is in accordance with previous data. ${ }^{1}$

The pathogenetic factors which may lead to Jaccoud's arthropathy have not yet been elucidated. Bywaters et al proposed fibrosis resulting from an inflammatory reaction, possibly related to an immunological stimulus. ${ }^{2}$ In general, inflammatory reactions of the joints in SLE are transient and, in many patients, of short duration. We hypothesised that patients with SLE and Jaccoud's arthropathy may have a persisting inflammation of the joints with infiltration of inflammatory cells, resulting in the production of cytokines such as interleukin 1 (IL 1) and IL 6, which may induce an acute phase reaction. ${ }^{14}$ In general, patients with SLE have a low $C$ reactive protein response, even during disease exacerbations. ${ }^{45}$ The theory of Bywaters, ${ }^{2}$ suggesting a persisting inflammatory reaction of the synovium, could be an explanation for the higher concentrations of $\mathrm{C}$ reactive protein that were found in our study in patients with Jaccoud's arthropathy compared with patients without Jaccoud's arthropathy. Persisting synovitis leading to joint laxity seems, however, not to be the only factor in the pathogenesis of Jaccoud's arthropathy. Bleifeld and Inglis showed that the hand deformities proceeded more rapidly in patients with a high disease activity for prolonged periods of time, even when disease activity did not include synovitis. ${ }^{15}$ This suggests that systemic factors may also be present. We found a higher occurrence of IgM rheumatoid factor in our patients with Jaccoud's arthropathy compared with those without, in accordance with AlarconSegovia et al. ${ }^{16} \mathrm{~A}$ possible part for rheumatoid factor has been suggested in the pathogenesis of Jaccoud's arthropathy by participating in the formation of immune complexes ${ }^{17}$ and, as such, acting as a local inducer of an inflammatory reaction.

In conclusion, our study showed higher concentrations of $\mathrm{C}$ reactive protein in patients with SLE and Jaccoud's arthropathy compared with patients without Jaccoud's arthropathy, despite comparable disease activity and treatment. This points to a chronic inflammatory reaction. Future studies should reveal whether treatment directed to normalisation of concentrations of $\mathrm{C}$ reactive protein will result in the prevention or stabilisation of Jaccoud's arthropathy in these patients.

1 Wallace D J, Dubois E L. Dubois' lupus erythematosus. 3rd ed. Philadelphia: Lea and Febiger, 1987: 325-6.

2 Bywaters E G L. Jaccoud's syndrome. Clin Rheum Dis 1985; 1: $125-48$.

3 Jaccoud F S. Sur une forme de rhumatisme chronique: leçions de clinique Médicale faites à l'Hopital de la Charité. Paris: Delahaye, 1869: 598-616.

4 Pepys M B, Lanham J G, de Beer F C. C-reactive protein in systemic lupus erythematosus. Clin Rheum Dis 1982 ; 8: 91-103.

5 Morrow W J W, Isenberg D A, Parry H F, Snaith M L. C-reactive protein in sera from patients with systemic lupus erythematosus. I R heumatol 1981; 8: 599-604.

6 Tan E M, Cohen A S, Fries J F, et al. The 1982 revised criteria for the classification of systemic lupus erythematosus. Arthritis Rheum 1982; 25: 1271-7.

7 Borg E J ter, Horst G, Hummel E J, Limburg P C, Kallenberg C G M. Measurement of increases in antidouble-stranded DNA antibody levels as a predictor of disease exacerbation in systemic lupus erythematosus. disease exacerbation in systemic
Arthritis Rheum 1990; 33: 634-43.

8 Arnett F C, Edworthy S M, Bloch D A, et al. The American Rheumatism Association 1987 revised criteria for the classification of rheumatoid arthritis. Arthritis Rheum 1988; 31: 315-24.

9 Leeuwen van M, Westra J, Limburg P C, et al. Quantitation of IgM, IgA and IgG rheumatoid factors by ELISA in of IgM, IgA and IgG rheumatoid factors by ELISA in rheumatoid arthritis and other rheumatic
I Rheumatol (Suppl) 1988; 75: 25-31.

10 Kallenberg C G M, Snijder J A M, Feltkamp T E W, The $T H$. Human fibroblasts as a substrate for titration of antinuclear antibodies. Scand $\mathcal{F}$ Rheumatol 1985; 14: 95-6.

11 Aarden L A, de Groot E R, Feltkamp T E W. Immunology of DNA. III. Crithidia luciliae: a simple substrate for the determination of anti-ds DNA with the immunofluoresence technique. Ann N Y Acad Sci 1975; 245: 505-15.

12 Nienhuis R L F, Mandema E. A new serum factor in patients with rheumatoid arthritis. The perinuclear factor. Ann Rheum Dis 1964; 23: 302-5.

13 Kurata N, Tan E M. Identification of antibodies to nuclear acidic antigens by counterimmunoelectrophoresis. Arthritis Rhewem 1976; 19: 574-80.

14 Gupta S. Cytokines: molecular and biological characteristics. Scand I Rhewematol Suppl 1988; 76: 189-201.

15 Bleifeld $C \mathrm{~J}$, Inglis $A$. The hand in systemic lupus erythematosus. I Bone Joint Surg (Am) 1974; 56: 1207-15.

16 Alarcon-Segovia D, Abud-Mendoza C, Diaz-Jouanen E, et al. Deforming arthropathy of the hands in systemic lupus erythematosus. I Rheweitol 1988; 15: 65-9.

17 Kramer L S, Ruderman J E, Dubois E L, Friou G J. Deforming noneroaive arthritis of the hands in chronic systemic lupus erythematosus (SLE). Arthritis Rhowim 1970; 13: $329-30$. 